\title{
Physiotherapeutic stimulation in infants with Down syndrome to promote crawling
}

\section{Estimulação fisioterapêutica em lactentes com síndrome de Down para ganho do engatinhar}

\author{
Gabrielly Rosa dos Santos (D), Layana Cardoso Cabral (D), Leticia Rodrigues Silva (D), \\ Jadiane Dionisio (D)*
}

Universidade Federal de Uberlândia (UFU), Uberlândia, MG, Brazil

\begin{abstract}
Introduction: Down syndrome (DS) is a genetic disorder characterized mainly by ligament laxity and hypotonia. Infants with this syndrome have substantial motor retardation also with crawling. To reach this motor milestone, postural control and head and neck control in the prone position are necessary. Seeking to avoid atypical muscular synergies and facilitate the execution of functional activities, the Bobath Concept aims to stimulate weight transfers, promoting motor acquisitions in the prone, supine, sitting and standing positions. Objective: To evaluate and compare crawling before and after the intervention through the Bobath Concept method in infants with DS. Method: A longitudinal, prospective, evaluative and interventional study was carried out. The sample was composed of 4 infants with DS, aged 7 to 24 months. There were three stages of treatment: evaluation in accordance with the Alberta Infant Motor Scale (AIMS); short term intervention by the Bobath Concept; and re-evaluation using the same scale. Results: According to statistical analysis, there was no significant difference between pre- and post-treatment ( $t-3.1705, p=0.0504)$. However, the results obtained by evaluation and reevaluation, showed progress in infants' activity, the greatest progress being in the prone position. Infant 4 had the most satisfactory result, in percentage, as much as in the prone position
\end{abstract}

*GRS: BS, e-mail: gaby_rosadossantos@hotmail.com

LCC: BS, e-mail: layanacardoso@outlook.com

LRS: Master's student, e-mail: leticiars22@hotmail.com

JD: PhD, e-mail: jadydionisio@ufu.br 
(evolving 9.5\%), as in general (evolving 22.4\%). Conclusion: Infants submitted to intervention with the Bobath Concept obtained evolution in motor development, when comparing before and after therapy.

Keywords: Down Syndrome. Motor Disturbances. Early Stimulation. Infant. Locomotion.

\section{Resumo}

Introdução: A Síndrome de Down (SD) é uma alteração genética caracterizada principalmente pela frouxidão ligamentar e hipotonia. Os lactentes portadores dessa síndrome possuem atraso motor significativo, incluindo no engatinhar. Para alcançar este marco motor, é necessário controle postural, controle de cabeça e pescoço na posição prona. Buscando evitar as sinergias musculares atípicas e facilitar a execução de atividades funcionais, o Conceito Bobath permite estimular as transferências de peso, promovendo aquisições motoras nas posturas de prono, supino, sentado e em pé. Objetivo: Avaliar e comparar o engatinhar antes e após a intervenção através do Conceito Bobath em lactentes com SD. Método: Foi realizado um estudo longitudinal, prospectivo, avaliativo e intervencionista. A amostra foi composta por 4 lactentes de 7 a 24 meses com diagnóstico de SD. Foram realizadas 3 etapas de tratamento: avaliação através da escala AIMS; intervenção à curto prazo através do Conceito Bobath; e reavaliação pela mesma escala citada anteriormente. Resultados: Ao realizar a análise estatística não foi observada diferença significativa no pré e pós-tratamento (t: -3.1705, p: 0,0504). Entretanto, nos resultados obtidos por meio da avaliação e reavaliação, foi observado que houve progressão das atividades dos lactentes, sendo o maior progresso obtido na postura prono. O lactente 4 foi o que obteve resultado mais satisfatório, em percentis, tanto na posição prona (evoluindo 9,5\%), quanto no geral (evoluindo 22,4\%). Conclusão: Os lactentes submetidos à intervenção com o Conceito Bobath obtiveram evolução no desenvolvimento motor, quando comparados antes e após terapia.

Palavras-chave: Síndrome de Down. Distúrbios Motores. Estimulação Precoce. Lactente. Locomoção.

\section{Introduction}

Down syndrome (DS) is a genetic disorder that occurs due to the presence of an extra chromosome, namely a trisomy of chromosome 21 [1]. This syndrome is commonly characterized by being related to muscle hypotonia, ligament laxity and muscle weakness, which results in changes in dynamic balance and postural control [2]. The early intervention of physiotherapy is indicated to stimulate the acquisition of the infant's motor skills, promoting improved posture, balance and coordination of activities [3].

Infants with DS have significant motor delay, and this may be related to their bodily restrictions, such as joint hypermobility and muscle hypotonia. These characteristics hinder the movements to be performed and consequently impair the development of the body scheme. The body scheme is the overall, scientific and differentiated image of the body itself, being essential for the infant's psychomotor development $[4,5]$. These restrictions are also responsible for the slow movements and low postural control present in DS. Changes in the vestibular, visual, somatosensory and proprioceptive systems are also responsible for motor delay, as the hypotonia of these infants makes it difficult to acquire experiences and explore the environment $[4,6,7]$.

Crawling usually occurs in the period from the 6th to the 14 th month of life [8]. For this activity to be performed, the infant needs a tonic force to distribute the weight of his body in 4 supports. From this, the infant manages to displace its center of gravity, generating the gain of spatial acquisition by exploring the environment [9]. It is during crawling that the infant comes into contact with several different stimuli, such as tactile, kinesthetic and proprioceptive receptors. It is this information received during all the movement that will build the child's space-body notion $[6,10,11]$. In addition, this behavior exposes the infant to various visual and auditory stimuli, allows the control and movement of the 
head in all directions and stimulates the displacement of the lower limbs [6].

Researches show that infants with DS have significant motor delay in all postures, when compared to typical infants [3]. Such a delay directly affects the child's independence and exploration of the environment [3]. The acquisition of motor skills in DS are the same and follow the same order as in typical infants; however, this gain in new skills occurs later $[4,6]$. Accordingly, the aim of early physical therapy intervention is to gain motor skills in prone, supine, sitting and standing positions [4].

Since the infant with DS has significant motor impairment, it is observed that there is a delay in the development of cervical control, rolling, lying to sitting transition, standing and walking [12]. The benefit of therapies that stimulate motor development and postural control is very great for these children. This fact makes this research essential, to prove the effects of early stimulation in reducing motor delay in crawling in this population. This type of stimulation helps postures to support motor and cognitive development of infants with disabilities, through varied stimuli that will have an impact on neuronal maturation [13].

According to Silva [14], the Bobath Concept uses exercises that encourage weight transfers, making use of assistive materials such as Swiss ball and rollers. In this way, the patient learns to obtain greater proprioceptive control and spatial notion. Other authors also emphasize the effectiveness of the Bobath Concept as an instrument that avoids abnormal muscle synergies, reduces the interference of abnormal tone and facilitates the performance of functional activities [15].

The aim of this study was to evaluate and compare motor development in crawling before and after the Bobath Concept in infants with DS. The hypotheses stipulated were: infants with DS have significant delay in crawling due to muscle hypotonia, and therefore, they score below ideal in the Alberta Infant Motor Scale (AIMS); and the use of the Bobath Concept helps to improve postural control, contributing to an increase in walking capacity and consequently a reduction in crawling delay.

\section{Method}

The study had a longitudinal, prospective, evaluative and interventionist nature. After approval by CEP/UFU with CAAE No. 71359317.7.0000.5152, parents of infants participating in the extension project for children with DS at the Physiotherapy Clinic at Universidade Federal de
Uberlândia (UFU) were asked to allow their child's participation in this study. Parents and legal guardians who agreed to participate signed an informed consent form.

Inclusion criteria were: patients diagnosed with DS, between 7 months and 2 years in age, both sexes and all ethnicities, and informed consent form signed by parents or legal guardians. The non-inclusion criteria were: patients with orthopedic conditions and individuals with DS who had grade III or IV peri- and intraventricular hemorrhage. The discontinuity criterion considered 2 consecutive missed sessions since this impairs the motor learning process, which must be uninterrupted so that good results can be obtained at the end of the study. Thus, the study included 4 infants who met these criteria.

\section{Procedures}

The study was divided into three stages. The first stage consisted in an assessment of motor skills using AIMS. In the second stage, physiotherapeutic treatment was performed for 3 months, consisting of 2 sessions per week (total therapy). In the third stage, there was reassessment using AIMS. Treatment was based on the Bobath Concept with 50-minute therapy. Each stage was carried out by blinded independent researchers.

AIMS, developed by Piper and Darrah, observes the newborn's motor acquisitions up to the child's independent walking (approximately 18 months). There are 58 items in 4 different positions: prone, supine, sitting and standing. During the evaluation, the infant's motor behavior is observed, considering aspects such as weight support, posture and antigravity movements according to age. At the end of the evaluation, the collected data are transformed into percentiles ranging from 5 to $90 \%$ [16-18]. The percentiles allow one to categorize the infant's performance results according to the following criteria: a) normal/expected motor performance when the test result is above $25 \%$; b) suspicious motor performance when the result is between 25 and 6\%; and c) abnormal motor performance when the result is less than or equal to $5 \%$. Such a scale can be used both in term and preterm patients, considering the corrected age of premature infants $[16,18,19]$.

With the use of AIMS, it is possible to observe the prone position of infants, this position being an important prerequisite for achieving antigravity movements [20]. Such movements are essential for infants to acquire postural control and head and neck control, also 
to develop stability of the scapular waist, weight bearing, displacement and reach [20]. These movements precede the crawling motor milestone, and for these reasons, the prone position is the focus of the work [20].

The Bobath Concept analyzes the motor development of a specific task through normal neuropsychomotor development [21], and alters functional performance to improve movement [22]. This concept is divided into 3 techniques: stimulation, inhibition and facilitation $[19,21]$. Facilitation can be used to activate or stabilize some musculature [21]. The Bobath Concept works with altering tone and improving muscle strength, influencing postural control and performance of movements and static or dynamic functional activities. The concept combines control and change in movement patterns and inadequate postures, prompting the infant to exercise the movement in a closer to normal fashion. The movements performed are active but controlled and guided by the therapist [16].

The exercise protocol performed in the second stage consisted of five activities: stretching the quadriceps, hamstrings and sural triceps, performed in 3 sets of 30 seconds each; pelvic mobilization exercise; strengthening of the quadriceps and gluteus maximus; strengthening of the abdominal obliques with the aid of a therapeutic roller; strengthening of the abdominal muscles and spinal erectors using the Swiss ball. At the end of each therapy, crawling was simulated with the infant in a quadrupedal position and with a band suspending the abdominal region to perform the movement on four supports. In this posture, the therapist encouraged the patient through visual and auditory stimuli to push forward.

Data collections were performed in a reserved room at the physiotherapy clinic of the UFU, with adequate lighting and room temperature, mattresses, EVA mats and toys suitable for the age of each child.

\section{Results}

The infants were identified by numbers 1, 2, 3 and 4. Infant 1 was characterized as a late male premature born with low weight. Infants 2, 3 and 4 were born at term and with the appropriate weight, two of whom were male and one female. Table 1 shows the characteristics of these patients.

According to Table 1, when performing the statistical analysis, no significant difference was observed in the pre- and post-treatment ( $\mathrm{t}:-3.1705, \mathrm{p}=0.0504)$.

Table 1 - Sample characterization

\begin{tabular}{|c|c|c|c|c|c|}
\hline Infant & & Infant 1 & Infant 2 & Infant 3 & Infant 4 \\
\hline Sex & & Male & Female & Male & Male \\
\hline Race & & White & White & White & White \\
\hline Prenatal complication & & Thyroid alteration & No & No & $\begin{array}{c}\text { Gestational } \\
\text { hypertension }\end{array}$ \\
\hline Term/preterm & & Preterm & At term & At term & At term \\
\hline Gestational age & & 34 weeks & 38 weeks & 38 weeks & 38 weeks \\
\hline \multirow{2}{*}{$\begin{array}{l}\text { Chronological } \\
\text { age (weeks) }\end{array}$} & Evaluation & $356 / 7$ & 69 & $41^{6 / 7}$ & 51 \\
\hline & Reevaluation & $52^{3 / 7}$ & $75^{5 / 7}$ & $57^{3 / 7}$ & 64 \\
\hline \multirow{2}{*}{$\begin{array}{l}\text { Corrected } \\
\text { age (weeks) }\end{array}$} & Evaluation & $29^{1 / 7}$ & ---------- & --------- & --------- \\
\hline & Reevaluation & $46^{4} / 7$ & --------- & --------- & --------- \\
\hline \multirow{2}{*}{ Weight } & At birth & $2.050 \mathrm{~kg}$ & $2.450 \mathrm{~kg}$ & $3.20 \mathrm{Kg}$ & $2.535 \mathrm{~kg}$ \\
\hline & Evaluation & $6.690 \mathrm{~kg}$ & $8.330 \mathrm{~kg}$ & $7.01 \mathrm{Kg}$ & $7.6 \mathrm{~kg}$ \\
\hline \multirow{2}{*}{ Height } & At birth & $42 \mathrm{~cm}$ & $44 \mathrm{~cm}$ & $48.5 \mathrm{~cm}$ & $46 \mathrm{~cm}$ \\
\hline & Evaluation & $61.5 \mathrm{~cm}$ & $68.9 \mathrm{~cm}$ & $66 \mathrm{~cm}$ & $69 \mathrm{~cm}$ \\
\hline Therapy & & 24 & 24 & 24 & 24 \\
\hline Missed therapy & & 6 & ---------- & 1 & ---------- \\
\hline
\end{tabular}




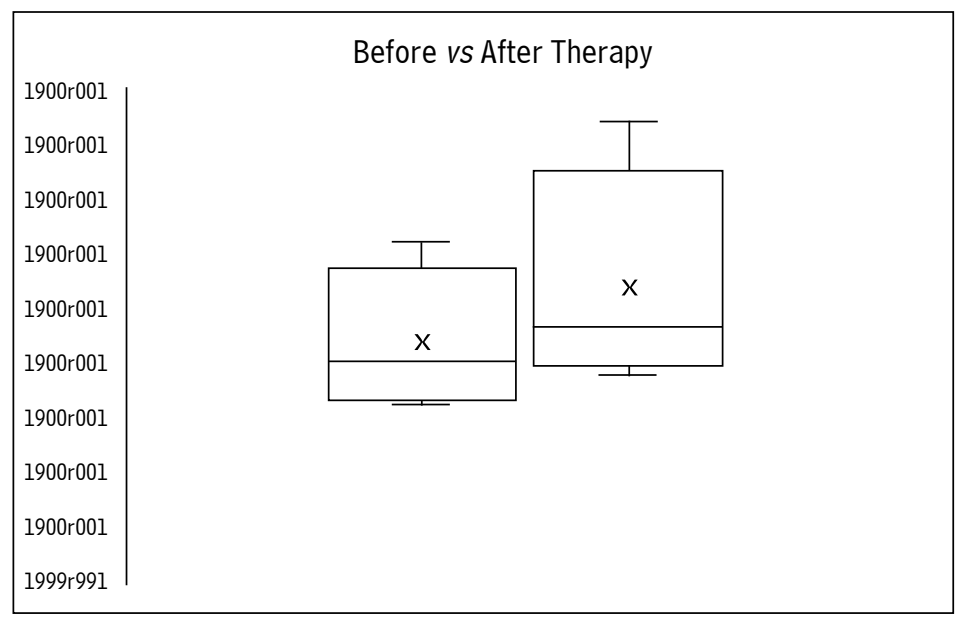

Figure $\mathbf{1}$ - Comparison before and after treatment.

Table 2 represents the results in percentiles obtained on AIMS before and after treatment. We observed the evolution of the motor development of the four infants on AIMS, and infant 4 achieved a more satisfactory result, in percentiles, both in the prone position (evolving 9.5\% after the intervention), and in general (evolving $22.4 \%$ after intervention). The same results are shown in Figure 2.

Table 2 - AIMS results before and after therapy

\begin{tabular}{lccccccccc}
\hline & \multicolumn{2}{c}{ Infant 1 } & \multicolumn{2}{c}{ Infant 2 } & \multicolumn{2}{c}{ Infant 3 } & \multicolumn{2}{c}{ Infant 4 } \\
AlMS \% & $\begin{array}{c}\text { Before } \\
\text { therapy }\end{array}$ & $\begin{array}{c}\text { After } \\
\text { therapy }\end{array}$ & $\begin{array}{c}\text { Before } \\
\text { therapy }\end{array}$ & $\begin{array}{c}\text { After } \\
\text { therapy }\end{array}$ & $\begin{array}{c}\text { Before } \\
\text { therapy }\end{array}$ & $\begin{array}{c}\text { After } \\
\text { therapy }\end{array}$ & $\begin{array}{c}\text { Before } \\
\text { therapy }\end{array}$ & $\begin{array}{c}\text { After } \\
\text { therapy }\end{array}$ \\
Prone & $28.6 \%$ & $33.3 \%$ & $28.6 \%$ & $33.3 \%$ & $28.6 \%$ & $38.1 \%$ & $85.7 \%$ & $95.2 \%$ \\
Supine & $44.4 \%$ & $55.5 \%$ & $100 \%$ & $100 \%$ & $88.9 \%$ & $88.9 \%$ & $55.5 \%$ & $100 \%$ \\
Sitting & $58.3 \%$ & $66.6 \%$ & $75 \%$ & $83.3 \%$ & $41.7 \%$ & $75 \%$ & $83.3 \%$ & $100 \%$ \\
Standing & $12.5 \%$ & $12.5 \%$ & $6.25 \%$ & $12.5 \%$ & $12.5 \%$ & $12.5 \%$ & $18.7 \%$ & $50 \%$ & $84 \%$ \\
Total & $32.7 \%$ & $37.9 \%$ & $44.8 \%$ & $48.3 \%$ & $36.2 \%$ & $46.5 \%$ & $62.1 \%$ & $84.5 \%$ \\
\hline
\end{tabular}

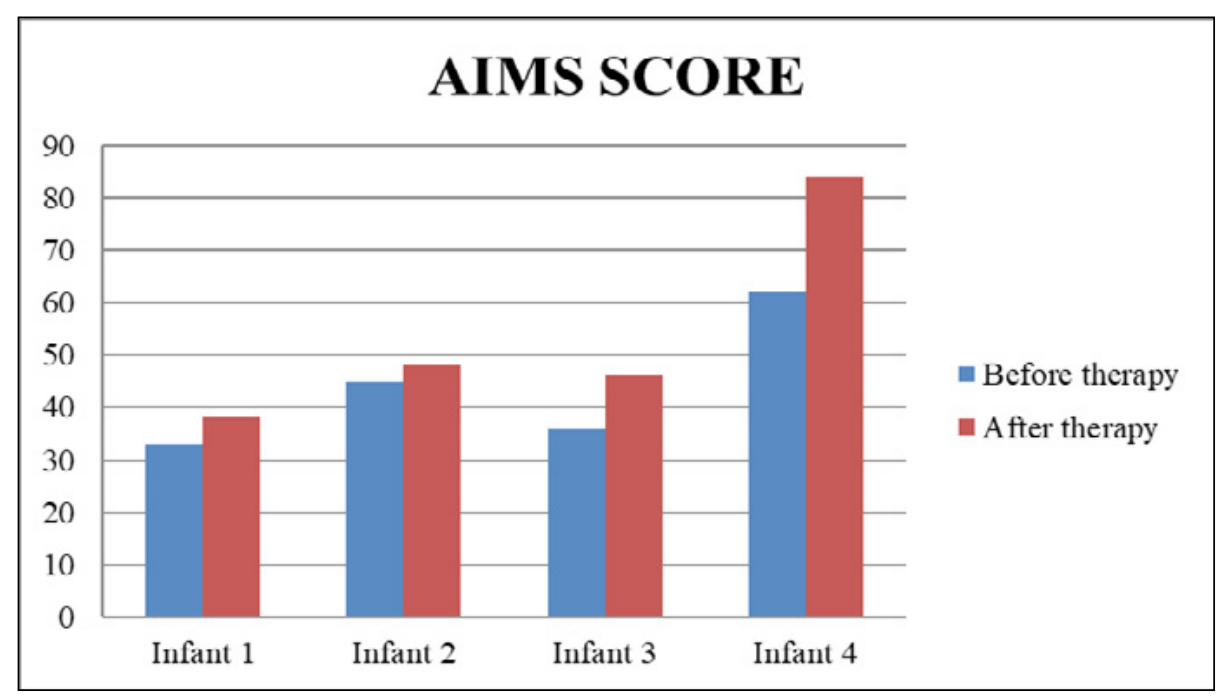

Figure 2 - AIMS results before and after therapy. 


\section{Discussion}

The aim of the present study was to compare and analyze the results of an early intervention, using the Bobath Concept, in infants with DS, and accordingly, we submitted the infants to 24 clinic therapies. The results of this study showed that infants with DS had scores below the pre-established normal range for chronological age. This low score was observed both before and after the intervention, confirming the first hypothesis that such infants have a significant delay in crawling. This delay is due to hypotonia, which correlates with delays in fine and global motor skills, ligament laxity, deficits in balance and postural control causing movement restrictions, and impairment of the exploration of the environment $[4,23]$.

At the end of the therapy, progress was seen in the activities of these infants, when comparing the AIMS results before and after treatment. The greatest progress was made in the prone position, which was the focus of the work, since it influences crawling activity. Borba et al. [24] used AIMS and compared the motor development of full-term and preterm infants. There was a significant difference in scores for the four postures studied, with children of the higher age group having the best performance. The best scores were obtained with the supine position, and the lowest scores were in the prone and standing positions [24].

The results of the evaluations and reevaluations after the 24 visits showed that there were motor gains in the four infants, which supports our second hypothesis that the Bobath Concept could reduce motor delay. The results of the study corroborate the findings of Sotoriva and Segura [25], who carried out a study aimed at determining the effect of the Bobath Concept on motor development in infants with DS. The authors concluded that this technique helps infants reach motor milestones in the best possible way and contributes to the gain of adequate and essential postural patterns for achieving other motor milestones [25]. Concomitantly, Firmino et al. [21] observed that this type of intervention increases the recruitment of muscle fibers, directly promoting the improvement of muscle function [21].

Lima et al. [26] found in their study that treatment combining conventional kinesiotherapy and the Bobath Concept provided satisfactory results for infants with DS, both in terms of muscle strengthening and proprioception, improving gross motor coordination.

Patient 2, who received continuous treatment, was a female and evolved 3.5\% according to the AIMS data, while patients 1, 3 and 4, who received interval treatment, were males and had a greater evolution. The influence of gender can be explained by various factors, including morphological, anatomical and hormonal factors. In the study by Coelho et al. [27], composed of participants of both sexes, unilateral motor strength and performance of the dominant upper limb was compared. These authors found that males had greater capacity for generating muscle strength, due to morphological and anatomical differences, since the area and diameter of muscle fibers are larger in males [27].

In addition, the sex of infants may have influenced the outcome, due to the hormonal differences that exist between males and females. According to Ramos et al. [28], the testosterone concentration in the body is one of the main factors for the differences in muscle mass and strength and in the response to treatment, this hormone being present in greater concentration in males [28]. Testosterone is an anabolic steroid hormone derived from cholesterol, with multiple physiological functions, such as growth and maintenance of bone matrix and skeletal muscle, in addition to influencing the synthesis of neurotransmitters, which are important for muscle contraction [29]. Thus, when women, who have a lower physiological concentration of this hormone compared to men, undergo continuous treatment, they may not show the expected results or may show inferior results [28].

Peres et al. [30] observed an improvement in tone, muscle strength and functional activities after using the Bobath Concept in patients with spastic diparesis. Other authors have also concluded the efficacy of this intervention in children with chronic non-progressive encephalopathy [31]. According to Duarte and Rabello [31], the aim of Bobath Concept is to facilitate physiological movement and to promote the child's maximum functional potential, as it encourages skills, motor development and the child's interactions with the environment.

Given the above and the results obtained by the AIMS scale, it appears that early intervention programs are extremely necessary to facilitate postures and favor neuropsychomotor development [26,32]. Trindade and Nascimento [4], in their study with seven children with DS, concluded that intervention programs contribute to the reduction of motor delay in these patients. However, the earlier this intervention, the greater the chances are of motor skills developing sooner [4].

Okada et al. [33] conducted a retrospective study between April 1984 and September 2018 with the aim of assessing the relationship between the effectiveness of 
motor rehabilitation and the beginning of independent walking in children with SD. The sample consisted of 40 children with SD divided into two groups: early intervention group (before 6 months of age) with 17 patients and conventional intervention group (after 7 months) with 23 patients. The results showed that the motor rehabilitation completed before being capable of independent walking was significantly associated with the corrected age at the beginning of walking; that is, early motor rehabilitation can contribute to a better development of gross motor movement in children with SD.

In the systematic review carried out by González et al. [34], analyzed and evaluated different physical therapy interventions in infants with SD. The results showed that, with resistance training, there was improvement in the strengthening of the upper and lower limbs, which is in line with the studies previously mentioned about the importance of physical therapy in motor development in children with SD.

The present study was a case study carried out with a small sample (four infants), which makes it difficult to relate intervention with the desired results. Therefore, we suggest that more studies be conducted on the topic addressed there, given the scarcity in the literature.

\section{Clinical Implications}

The crawling process begins with the infant's attempts to move the trunk forward, followed by the development of muscle strength in the arms to support the suspended abdomen. Finally, there are the movements of crawling hands and knees, promoted by the diagonal coordination of arms and legs [35].

In infants with DS, the basic motor milestones occur later in comparison to children who do not have the syndrome, and for this reason, it is necessary to have an early intervention in these children to favor the stimulation of motor development [1]. In the present study, an early intervention was provided with the application of the Bobath Concept, and improvement in motor skills was seen, mainly in the prone position, which influences crawling activity. This result was obtained because one of the objectives of the Bobath Concept is to increase the number of motor units recruited, thereby increasing muscle strength [21] and improving balance and postural control [36].

\section{Conclusion}

In view of the results obtained in this study and the perspective of anticipated motor gains in children with DS, we conclude that infants submitted to intervention with the Bobath Concept show progress in motor development, when comparing before and after therapy. Since this intervention, when provided early, will help to reduce motor delay in crawling in these children and favor development.

\section{References}

1. Scapinelli DF, Laraia ÉMS, Souza AS. Evaluation of functional capabilities in children with down syndrome. Fisioter Mov. 2016;29(2):335-42.

2. Mello BC, Ramalho TFR. Use of virtual reality in the physical therapeutic treatment of individuals with down syndrome. Rev Neuroc. 2015;23(1):143-9.

3. Leite JC, Neves JC J, Vitor LGV, Fujisawa DS. Controle postural em crianças com síndrome de down: avaliação do equilíbrio e da mobilidade funcional. 2018;24(2):173-82.

4. Trindade AS, Nascimento MA. Avaliação do desenvolvimento motor em crianças com síndrome de down. Rev bras Educ espec. 2016;22(4):577-88.

5. Pereira K, Basso RP, Lindquist ARR, Silva LGP, Tudella E. Infants with down syndrome: percentage and age for acquisition of gross motor skills. Res Dev Disabil. 2013;34(3):894-901.

6. Torquato JA, Lança AF, Pereira D, Carvalho FG, Silva RD. A Aquisição da motricidade em crianças portadoras de síndrome de down que realizam fisioterapia ou praticam equoterapia. Fisioter Mov. 2013;26(3):515-25.

7. Knychala NAG, Oliveira EA, Araújo LB, Knychala NAG, Araújo LB, Azevedo VMGO. Influência do ambiente domiciliar no desenvolvimento motor de lactentes com síndrome de down. Fisioter Pesqui. 2018;25(2):202-8.

8. Pereira KRG, Saccani R, Valentini NC. Cognição e ambiente são preditores do desenvolvimento motor de bebês ao longo do tempo. Fisioter Pesqui. 2016;23(1):59-67. 
9. Costa NMS. O desenvolvimento da locomoção em interações bebê-bebê no contexto de creche. Ribeirão Preto [master's thesis]. São Paulo: Universidade de São Paulo; 2017.

10. Toble AM, Basso RP, Lacerda AC, Pereira K, Regueiro EMG. Hidrocinesioterapia no tratamento fisioterapêutico de um lactente com Síndrome de Down: estudo de caso. Fisioter Mov. 2013;26(1):231-8.

11. Fernandes PV, Gerzson LR, Almeida CS, Spessato BC. Desenvolvimento da manipulação do bebê em diferentes idades motoras. R Bras Ci e Mov. 2017;25(1):99-108.

12. Cardoso ACN, Campos AC, Santos MM, Santos DCC, Rocha NACF. Motor Performance of children with down syndrome and typical development at 2 to 4 and 26 Months. Pediatr Phys Ther. 2015;27(2):135-41.

13. Morais KDW, Fiamenghi-Jr GA, Campos D, Blascovi-Assis SM. Profile of physiotherapy intervention for Down syndrome children. Fisioter Mov. 2016;29(4):693-701.

14. Silva TF. A Importância do Método Bobath na reabilitação de criança com paralisia cerebral. Rev Cient Multi Núcleo Conhece. 2017;2(5):15-23.

15. Oliveira LDS, Golin MO. Técnica para redução do tônus e alongamento muscular passivo: efeitos na amplitude de movimento de crianças com paralisia cerebral espástica. ABCS Health Sci. 2017;42(1):27-33.

16. Mello EQ Gallo SM, Goulart FC, Herrero D, Gallo PR. Motor development of brazilian breastfeeding infants in socially unfavorable condition of life. J Hum Growth Dev. 2014;24(2):163-7.

17. Silva LP, Maia PC, Lopes MMCO, Cardoso MVLML. Intraclass reliability of the Alberta Infant Motor Scale in the Brazilian version. Rev Esc Enferm USP. 2013;47(5):1046-51.

18. Venturella CB, Zanandrea G, Saccani R, Valentini NC. Motor development of children between 0 and 18 months of age: Differences between sexes. Motri. 2013;9(2):3-12.

19. Pagnussat A S, Simon AS, Santos CG, Postal M, Manacero $S$, Ramos RR. Atividade eletromiográfica dos extensores de tronco durante manuseio pelo Método Neuroevolutivo Bobath. Fisioter Mov. 2013;26(4):855-62.

20. Senju A, Shimono M, Tsuji M, Suga R, Shibata E, Fujino $\mathrm{Y}$, et al. Inability of infants to push up in the prone position and subsequent development. Pediatr Int. 2018;60(9):811-9.
21. Firmino R, Lima AK, Almeida C, Uchôa S. Influence of Bobath's Concept on muscle function of the spastic tetraplegia cerebral palsy. Rev Neurocienc. 2015;23(4):595-602.

22. Vaughan-Graham J, CottC, Wright FV. The Bobath (NDT) concept in adult neurological rehabilitation: what is the state of the knowledge? A scoping review. Part II: intervention studies perspectives. Disabil Rehabil. 2015;37(21):1909-28.

23. Malak R, Kotwicka M, Krawczyk-Wasielewska A, Mojs E, Samborski W. Motor skills, cognitive development and balance functions of children with Down syndrome. Ann Agric Environ Med. 2013;20(4):4.

24. Borba LS, Saccani R, Valentini NC. Desenvolvimento motor de crianças nascidas pré-termo e a termo avaliadas com a escala motora infantil de alberta. Temas Desenvolv. 2013;19(105):130-5.

25. Sotoriva P, Segura DCA. Aplicação do método Bobath no desenvolvimento motor de crianças portadoras de síndrome de down. Saude Pesqui. 2013;6(2):8.

26. Lima JL, Mélo TR, Costin ACS, Neves EB. Terapia neuromotora intensiva nas habilidades motoras de criança com Síndrome de Down. Rev Bras Pesqui Saude. 2018;19(2):133-9.

27. Coelho RA, Zanetti HR, Cruz LG, Jesus MAF, Haddad EG. Força e resistência muscular de membro superior dominante e não dominante no exercício de flexão unilateral de antebraço: comparação entre os sexos. Rev Bras Fisiol Exerc. 2017;16(2):42-8.

28. Ramos HC, Morales PJ, Souza WC, Brasilino MF, Brasilino FF. Análise da força muscular dos membros inferiores em mulheres praticantes de musculação nas diferentes fases do ciclo menstrual. Rev Bras Fisiol Exerc. 2018;12(72):29-37.

29. Cavalcanti BA, Rosa JPP, Silva A, Ferreira D. Interação entre os hormônios testosterona, cortisol e aspectos psicobiológicos no exercício físico: uma revisão integrativa. Rev Ed Fisica. 2016;85(4):406-18.

30. Peres LW, Ruedell AM, Diamante C. Influência do conceito neuroevolutivo bobath no tônus e força muscular e atividades funcionais estáticas e dinâmica sem pacientes diparéticos espásticos após paralisia cerebral. Rev Saude. 2009;35(1):28-33. 
31. Duarte MP, Rabello LM. Conceito neuroevolutivo bobath e a facilitação neuromuscular proprioceptiva como forma de tratamento para crianças com encefalopatia crônica não progressiva da infância. Rev Cient Fac Educ e Meio Ambient. 2015; 6(1):14-26.

32. Ribeiro DG, Perosa GB, Padovani FHP. Fatores de risco para o desenvolvimento de crianças atendidas em Unidades de Saúde da Família, ao final do primeiro ano de vida: aspectos sociodemográficos e de saúde mental materna. Cienc Saude Coletiva. 2014;19(1)2015-226.

33. Okada S, Uejo T, Hirano R., Nishi H, Matsuno I, Muramatsu T, Ishikawa Y. Assessing the efficacy of very early motor rehabilitation in children with down syndrome. J Pediatr. 2019;213:227-31.
34. González LR, Antón DR, Salazar A, Valero RM, Munoz JA. Physical Therapy in Down syndrome: systematic review and meta-analisys. J Intellect Disabil Res. 2019;63(8):1041-67.

35. Xiong QL, Hou WS, Xiao N, Chen YX, Yao J, Zheng XL, et al. Motor Skill Development Alters Kinematics and CoActivation Between Flexors and Extensors of Limbs in Human Infant Crawling. IEEE Trans Neural Syst Rehabil Eng. 2018;26(4):780-7.

36. Tekin F, Kavlak E, Cavlak U, Altug F. Effectiveness of NeuroDevelopmental Treatment (Bobath Concept) on postural control and balance in Cerebral Palsied children. J Back Musculoskelet Rehabil. 2018;31(2):397-403.

Received: 02/03/2019

Recebido: 03/02/2019

Approved: 02/03/2020

Aprovado: 03/02/2020 